\title{
Jean-Pierre Bertrand-Pascal Durand, Les poètes de la modernité
}

Ida Merello

\section{(2) OpenEdition}

\section{Journals}

\section{Edizione digitale}

URL: http://journals.openedition.org/studifrancesi/8318

DOI: $10.4000 /$ studifrancesi.8318

ISSN: 2421-5856

\section{Editore}

Rosenberg \& Sellier

\section{Edizione cartacea}

Data di pubblicazione: 1 mai 2009

Paginazione: 198

ISSN: 0039-2944

\section{Notizia bibliografica digitale}

Ida Merello, «Jean-Pierre Bertrand-Pascal Durand, Les poètes de la modernité», Studi Francesi [Online], 157 (LIII | I) | 2009, online dal 30 novembre 2015, consultato il 12 janvier 2021. URL: http:// journals.openedition.org/studifrancesi/8318; DOI: https://doi.org/10.4000/studifrancesi.8318

Questo documento è stato generato automaticamente il 12 janvier 2021.

\section{(c) (i) (9)}

Studi Francesi è distribuita con Licenza Creative Commons Attribuzione - Non commerciale - Non opere derivate 4.0 Internazionale. 


\title{
Jean-Pierre Bertrand-Pascal Durand, Les poètes de la modernité
}

\author{
Ida Merello
}

\section{NOTIZIA}

JEAN-PIERRE BERTRAND-PASCAL DURAND, Les poètes de la modernité, Paris, Seuil 2006, pp. 334.

1 L'opera offre una storia della poesia «stilistico-sociologica» della seconda metà del XIX secolo dal punto di vista del concetto di modernità e dell'evoluzione della nozione stessa attraverso le diverse generazioni poetiche. La modernità che interessa agli AA. non è legata alla referenzialità rispetto agli oggetti dell'innovazione tecnologica, quanto all'elaborazione di una nuova forma di poesia, che, ritagliatasi uno spazio autonomo, aspira di volta in volta a un diverso rapporto con l'esterno. Gli autori ripercorrono gli anni a partire dalla Rivoluzione del 1848, con una rilettura attenta anche dei rapporti tra letterati: ad esempio così è messa in rilievo la figura di Hugo, il cui ruolo incisivo nel panorama culturale si protrae ben oltre la metà del secolo, obbligando tutti i partigiani dell'arte per l'arte a confrontarsi col suo modello lirico e la sua immagine di poeta pubblico. Ampio spazio è poi dedicato a Baudelaire, e all'evoluzione delle sue riflessioni, che muovono dal concetto di ricerca dell'"epico" in ciascuna epoca, fino ad arrivare invece all'identificazione della poesia moderna con lo strumento capace di cogliere in ogni occasione storica l'assoluto nell'effimero. È in questo quadro teorico che Bertrand e Durand riesaminano alcuni autori che hanno fatto scuola - e fatto epoca - da Gautier a Banville a Lautréamont fino ai maudits, Jarry e l'Esprit Nouveau, in una pregevole ricostruzione della storia letteraria e del ruolo in essa delle grandi personalità. 